\title{
Innovations in Nigerian Universities: Perspectives of An Insider from A "Fourth Generation" University
}

\author{
Prof. (Mrs.) Grace Koko Etuk ${ }^{1}$ \\ ${ }^{1}$ Department of Curriculum Studies and Educational Management, University of Uyo, P.M.B. 1017, Uyo, Akwa \\ Ibom State, Nigeria \\ Correspondence: Prof. (Mrs.) Grace Koko Etuk, Department of Curriculum Studies and Educational Management, \\ University of Uyo, P.M.B. 1017, Uyo, Akwa Ibom State, Nigeria. Tel: 234-80-2329-7073. E-mail: \\ kokograce@rocketmail.com
}

Received: February 5, 2015

Accepted: April 28, 2015

Online Published: August 18, 2015

doi:10.5430/ijhe.v4n3p218

URL: http://dx.doi.org/10.5430/ijhe.v4n3p218

\begin{abstract}
This paper elaborates on innovations which have been effected in universities in Nigeria, using a somewhat young university as a paradigm. The innovations discussed include private ownership of universities, innovative funding strategies and innovative quality assurance practices. These include innovative planning (strategic planning); innovative programme contents; innovations in human and material resources development; innovative admission procedures; innovative carrying-capacity regulations; and innovative programme appraisal procedures and standards. The paper concludes by maintaining that innovation augurs well by improving programme standards and quality of products.
\end{abstract}

Keywords: Innovations, Quality assurance, Strategic planning, Accreditation, Funding, Marketing

\section{Introduction}

Federal universities in Nigeria are often categorized on the basis of the years that they were founded. This gives rise to first, second, third, fourth and so on, generation of Federal universities in Nigeria. Those that were established in the 1960s are often referred to as the first generation universities. The first generation universities include the University of Nigeria, Nsukka, which was founded on October one, 1960; the University of Lagos that was founded on October two, 1962; Ahmadu Bello University, Zaria, that was founded on October 10, 1962; the University of Ife, Ile-Ife, that was founded on October 24, 1962; the University of Ibadan that gained autonomy from the University of London, by ceasing to be a campus of the latter, on December 27, 1962. The University of Benin, although it was founded in 1970 is often counted among the first generation universities in Nigeria. The territory where the University of Benin is located was carved out of the former Western region of Nigeria in 1963. The University of Benin was founded in 1970 in order to satisfy higher education needs of that 'new' political entity. (Guobadia, 1983; Uwajeh \& Mohammed, 1988; Ocho, 2006).

The second generation universities in Nigeria are seven in number and they were all founded in 1975. These are the University of Maiduguri in Borno State; the University of Kano in Kano State; the University of Jos in Plateau State; the University of Calabar in Cross River State; the University of Illorin in Kwara State; the University of Port Harcourt in Rivers State and the University of Bauchi in Bauchi State. Except for the University of Maiduguri, Borno State, the other six were founded initially as campuses of the first generation universities. In due course, they all assumed their independence. The seven newly-founded second generation universities plus the six earlier ones added up to 13 universities in Nigeria in the year, 1975, when Nigeria assumed a 12-States political structure from her three former regions (the Eastern, Northern and Western regions of Nigeria ceased to exist in 1975). Each of the 12 newly create States that had no Federal university in its domain was given one (Etuk, 2006).

In 1976, seven new States were created and seven universities of technology were founded with each located in the seven new States that were then created. That gave Nigeria a 19-States structure and 19 federally managed and federally funded universities. Thus, universities of technology were the 'third generation' universities in Nigeria. From thence on there was an embargo on the creation of more States and more universities until 1991 when the next set of Federal universities were created under the military leadership of General Ibrahim Babagida. The University of Uyo happened to have been one the Federal universities that were founded in 1991. It was meant to give Federal 
tertiary education presence in Akwa Ibom State which was then carved out of Cross River State, which has the (Federal) University of Calabar. This explains why the University of Uyo, which was in the fourth group of Federal universities founded in 1991, is referred to in this paper as a 'fourth generation' university. The next embargo on establishing universities by the Federal government was lifted in 2013 under the Presidency of Dr. Goodluck Ebele Jonathan when nine new universities were founded. These nine became the fifth and the latest generation of Federal universities and added up to 38 Federal universities in Nigeria in the year, 2013.

The University of Uyo is a relatively young university. In terms of staff strength, the university has on its per roll 1405 teaching staff made up of 306 females and 1099 males; 1,143 senior non-teaching staff, consisting of 537 females and 606 males; and 250 junior non-teaching staff, comprising 600 females. These add up to 3798 staff.

Table 1. Staff strength at the University of Uyo in 2013/2014 Session

\begin{tabular}{llll}
\hline & Male & Female & Total \\
\hline Number of Academic Staff & 1099 & 306 & 1405 \\
Number of Senior Non-Teaching Staff & 606 & 537 & 1143 \\
Number of Junior Staff & 650 & 600 & 1250 \\
Total & & & $\mathbf{3 7 8 9}$ \\
\hline
\end{tabular}

Source: Personnel Department, university of Uyo. (2014, September).

The staff' are well distributed into the 12 Faculties, into the administrative units and into service departments like works, health and computer departments. Diversification in admissions is shown On Table 2

Established 23 years ago in 1991, the University of Uyo is a relatively young, Federal university in Nigeria as compared to universities which were established 30 years earlier, at the wake of the Nigerian independence in 1960, (these were earlier referred to in this paper as first generation Federal universities in Nigeria). Despite its young age, the University of Uyo can boast of 85 undergraduate programmes. Most of the undergraduate programmes also have post-graduate counterparts. These are spread into her 12 faculties, which are the Faculties of Agriculture, Arts/Humanities, Basic Medical Sciences, Business Administration, Education, Engineering, Environmental Studies, Law, Medicine, Pharmacy, Pure Sciences, Social Sciences. The School of Continuing Education also runs diploma programmes both at the undergraduate and postgraduate levels.

Table 2. Distribution of Students' populations in the 2012/2013 session at the University of Uyo

\begin{tabular}{lc} 
Programmes & Number of students en \\
\hline Regular undergraduates & 16,293 \\
Part-time undergraduates & 1,148 \\
Regular postgraduates & 2,436 \\
Part-time postgraduates & 673 \\
Pre-degree students & 124 \\
Basic studies students & 348
\end{tabular}

The total students' population in 2012/2013 Session is 21,022

Source: Ekpo, C. M. (2014, Aug.-Oct.). I have put structures in place that co-launch University of Uyo to World class. Education Today International (pp. 12-18)

Universities in Nigeria seem to be buying into the assertions that we are in the midst of rapid transformation in education across dimensions of purposes, contents, paedogogy and methodologies. Social change and decades of long trends of ever-increasing costs have left us with multiple challenges and the need to be highly innovative in our educational cultures and practices (Doss, 2014, July, 31). An innovation involves converting a new knowledge into brand new products and services (Kotelnikov, 2000). An innovative change involves a complete change of all the inputs and long-standing work methods in order to produce a completely new product or service. An innovative product or service has an added value (Robbins, 2000). 
It should be emphasized that, an innovative change must be planned for. It should not be a sudden, unexpected and a haphazard change. It should be a planned change which is "radical, multidimensional and multi-level" (Robbins, 2000). An innovative change may involve changing basic mores and cultures of the people, who are affected by the change. Examples from the Nigeria school system are the changes which accompanied the 6-3-3-4 educational structure, as experienced in 1976 at the primary level of education; in 1981 at the secondary level and at the university level in the 1985/86 session. Innovation in schools then was multi-dimensional in the sense that the educational structure, the learning contents, the teaching/learning materials including textbooks, were all changed. The classroom behaviours of teachers were expected to change too, as teachers were exposed to seminars, workshops, trainings and conferences which were funded by the Federal Ministry of Education. These were therefore, changes in inputs in anticipation of changes in the processes (teaching methods) and in the products (the students who completed the programmes).

This paper will hereafter, orchestrate recent innovations in the university system in Nigeria, as compiled from the perspective of a lecturer of many years in a not-that-old university in Nigeria. The University of Uyo in Southern Nigeria. These include innovation in ownership of universities, innovation in funding and innovation in quality control, in facilities and technology; innovation in students entrants routes, quality assurance through accreditation of educational programmes and accreditation of the entire educational institution.

\section{Innovation in Ownership of Universities in Nigeria}

Education in Nigeria has been deregulated. This means that education has been liberalized from former rules and controls. Deregulation centres around ownership and funding of tertiary education. In respect to ownership, education in Nigeria at inception in 1842 was under the management and control of voluntary agencies, which operated under different orthodox church groups in Nigeria. These included groups that are currently represented by the Anglican, the Methodist and the Presbyterian churches in Nigeria. The colonial government in Nigeria showed interest in education 40 years later (in 1882), when government granted thirty Nigerian pounds (£30) to the voluntary agencies towards education. From then onwards, government granted more and more funds as aid to the voluntary agencies towards education (Etuk, 2006).

The ultimate in government participation in education in Nigeria came after the Nigerian Civil War, precisely from 1970, when different newly-created State governments in Nigeria assumed the responsibility of managing and controlling education in their different territories. This is what is usually referred to in Nigeria as the 'State take-over of schools'. The originator of the state take-over of schools was the defunct East Central State of Nigeria currently represented by four States (Imo, Ebonyi, Anambra and Enugu States). The whole of that South-Eastern part of Nigeria was the centre of the Nigeria Civil War (1966-1970). The area was so devasted by the civil war that thereafter in 1970, the defunct East Central State government under the administration of Mr. Ukpabi Asika, took over the administration and control of schools from the church-based voluntary agencies. That action was motivated by the need to give equal educational opportunities as part of the rehabilitation efforts of government. In the ensuing years, other State governments followed suit and took over management, funding and control of schools from voluntary church agencies, private individuals and organisations.

The control and financing of tertiary educational institutions which were founded in the 1960s were then firmly under the Federal government of Nigeria. As more and more States were created in Nigeria, more and more tertiary institutions (particularly universities) were established in the new States for parity purposes. That gave rise to Federally-managed and State-managed tertiary institutions. The latter were founded by different State governments where the Federal government did not establish one, some States that had a Federal institution added a State institution on their own.

The creation of more and more tertiary institutions was driven by increased social demand for tertiary education. The take-over of schools from voluntary agencies opened doors of educational opportunities for all and sundry, including children from poor parental backgrounds, who benefitted from the day-schooling practices of community schools, which were established consequent on the State take-over of schools. Increased number of secondary school products translated into increased social demand for tertiary education. Predictably, increased demand created problems of access and massification (Zeelen, 2012). Ojiabor (2005) cited a release by the National Universities Commission (N.U.C.) to the effect that out of 890, 300 candidates who then took the University Matriculation Examination (U.M.E.) in Nigeria, only 160,000 (roughly, 18 percent) of the candidates were admitted.

In the attempt to create more tertiary education opportunities to qualified candidates, and to ease the pressure of social demand for university education the Federal government of Nigeria deregulated university education. That means that management and control of university education which were under the exclusive list were then 
transferred to the concurrent legislative list of the Federal government of Nigeria. As at now, able individuals and organisations are authorized to establish universities in Nigeria. Deregulation of university education started since 1992 when government granted licenses for the establishment of Igbenedion, Madonna and Babcock universities (Olugbile, 2006). Nigeria is currently blessed with 91 universities. These include 38 federal universities, including the National Open University; 35 State universities and 28 private universities (cf. Etudor-Eyo, 2011).

\section{Traditional School Funding Models}

School funding models are propositions which seek to establish the rightful person or group that should bear the financial responsibility for educating the citizens of a country. Various suggestions have been proffered and reasons given as to who should fund education in a country. The four theoretical models for funding education include:

- The Full Support model;

- The Privatisation model;

- $\quad$ The Partial Support model (Ogar, 1992, p. 40)

\subsection{The Full Support Model of Funding Education}

This is a model which suggests that the State (government) should assume full responsibility for funding all levels and types of education located within its domain. The full support model makes education the constitutional responsibility of the State. Based on Ogar (1992) and Etuk (2006; 2011), the full support model of funding education was first advocated by Harbison in (1973). Reasons for allocating full responsibility for education funding to the State as contained in Etuk (2011) include the following:

1) The state collects taxes from taxable adults, properties, businesses, companies and on sundry matters within its domain. Therefore, part of the tax monies should be used for funding education.

2) Educated citizens are human resources for national development, therefore, the State should sponsor their education.

3) When education is funded by the State, every citizen will have equal opportunity of being educated (pp. 57-58).

\subsection{The Privatisation Model of Funding Education}

The privatisation model is a sharp contrast to the full support model. Advocates of the privatisation model maintain that education should be entirely privately-funded by the people who benefit from it. In other words, there should be no public schools. All schools, from the pre-primary through the tertiary level, should be private schools. Market forces should adjust the demand for and the supply of education through the price mechanism. That is, the demand for education by the societal members should determine the quantity and the quality of educational services supplied. Increase in the demand for each type of education would force private individuals to open more of such schools.

\subsection{The Partial Support Model}

The partial support model for funding education advocates that funding education should be a joint responsibility of the State (government) and other educational stakeholders. These include the parents whose children are educated, members of the community from where the child comes, firms operating within the community, philanthropic individuals, organisations, and so on. Citing Ogar, Etuk (2006) identified two main twists (versions) to the partial support model. These are:

- the equalisation version; and

- the equality of access version (p. 58)

\subsubsection{The Cubberly Equalisation Version of the Partial Support Model}

The equalisation version of the partial support model is always qualified by the name 'Cubberly', which is the name of the person who first postulated the equalisation model (Ogar, 1992). The Cubberly equalisation version of the partial support model maintains that the State (government) should provide:

i) support to maintain desirable standards of instruction to all children; and

ii) financial rewards to tax efforts (Etuk, 2006, p. 59 citing Cubberly).

What this implies is that wealthy communities that, presumably, pay more taxes, should be allocated more state funds per unit of their educational needs. In other words, any community that increases its local tax effort should receive extra amount of funds for education from government, as a reward for tax efforts. In the corollary, State 
funds allocated for education in a particular community should be in proportion to the amount of tax collected from that community. Extra tax efforts should receive extra rewards in terms of education funding. This version is often criticized for being inconsistent with equality principle of government.

\subsubsection{Strayers's Equality of Access Version of the Partial Support Model}

As with the equalisation version of the partial support model, the Equality of Access version is always qualified by the name 'Strayer', being the name of the person who first proposed that idea. Strayer, in Etuk (2006) proposed that the State should:

i) give equal funding to education in every community; and

ii) communities that are wealthy enough should complement the State's educational provisions at their own expense, any particular rich educational programme that they envisage, so as to attain the quality of education desired for their children (p.59). This is the educational funding option currently used in Nigeria.

\section{Innovative Funding Models used in Universities in Nigeria}

Higher educational institutions in Africa are now expected to borrow a leaf from American institutions (Juma, 2007). They are to stop being unduely dependent on government for funding. Universities in Nigeria are advised to source for funds from other sources such as Foundations, the private sector, endowments and from the alumni (Soludo, 2004). Universities are also expected to generate their own revenue by engaging in businesses, entrepreneurial activities and in marketing. They are to stop completely leaning on government for financial support. To this end, Lamptey (1994) recommended certain marketing models for funding university education in Africa. According to Lamptey (1994) all organisations (higher educational institutions inclusive whether they are conscious of it or not), are involved in marketing, once they are involved in exchange relationships. This is because higher educational institutions relate with students, parents, employers of labour, Alumni, donors and donor agencies, with faculty and with government. To ensure that the expectations of these different groups are met and that institutional objectives are achieved, higher educational institutions, though considered a non-profit sector, should borrow contemporary marketing concepts, tools and models, which have worked so effectively in managing products and services in the profit sector.

The reason for this recommendation is that education is dynamic and, therefore, change and innovation are as vital as they are in any other industries. To this end, higher educational institutions in Africa are urged to use the American model of funding higher education which draws very much from the Alumni, industrial establishments and from endowments. Lamptey (1994, p.6) recommended the use of the model called "Marketing Mix Conceptual Framework", which has four Ps with each P representing product, price, place and promotion, respectively. Each of these is elaborated upon in the following paragraphs and their relevance to university funding established.

\subsection{Marketing Through Diversification of Admissions and Outsourcing (product mix)}

Based on Lamptey (1994, p.6) product mix are in the managerial realm; and they concern managerial planning and decisions on what products or services to produce or sell. What varieties customers prefer, what styles, sizes, shapes and colours are preferable by customers. This implies that higher educational institutions in Africa, including in Nigeria, should ask relevant questions related to the needs and expectations of their markets. They should ask such questions as: What are the expectations of future employers?. What purpose does society expect higher education to serve? (p. 6). According to Lamptey (1994) product and service planning decisions are based on market research.

If higher educational institutions in Africa are to survive, and become competitive, they need to be responsive to the needs of their markets. In sourcing for funds, Lamptey (1994) recommended that universities should take the following steps:

i) Introduce course credit and semester systems to provide greater flexibility in course offerings available to students and to enhance efficiency in the teaching functions.

ii) Review the curriculum to accommodate changes in the entire education process, in particular to cater for senior secondary school products who will enter with different backgrounds and qualifications.

iii) Assess current textbooks and teaching materials.

iv) Institute marketing research in close association with academic and professional groups and with employers of labour.

v) Assess the rate of absorption of graduates into employment. 
vi) Assess the performance of graduates on their jobs.

vii) Provide consultancy services (pp. 6-7).

Most of the suggestions have been implemented in the author's university, which has a success story to tell.

\subsection{Innovative Funding Through Charging Discriminatory Prices (price mix)}

In an educational setting, price refers to money paid on services rendered (Lamptey, 1999). Bayer, (2014, July 31) a chief executive officer (CEO) of a firm which specializes in higher education products, nevertheless differentiates price from costs. The source maintains that higher educational institutions talk about costs while educational consumers talk about price. In that respect, price paid by students include students' application fees, registration, tuition, examination and rent on boarding and lodging by students. Costs in that sense, refers to salaries, allowances and honoraria paid for services rendered in educational institutions (Lamptey, 1999) observed that prices paid for services rendered in higher educational institutions in Africa are set at very unrealistic levels (Juma (2007) and Zeelen (2012) observed the same thing. Based on those authorities, prices paid are particularly so if the higher educational institution is a public institution. The price paid is often unrelated to costs because prices are determined by government policies, which assume that students cannot afford the cost of their education. In the opinions of these authorities, low price policy is disadvantageous because it cripples the ability of universities to recover costs.

Although higher educational institutions in Nigeria are bound by policy not to charge tuition fees, universities are, however, permitted to generate revenue through charging for other services rendered to students, like development fees, hostel fees and examination fees. Bearing in mind that higher education attracts much higher costs than the lower levels of, it is generally reasoned that cost bearing should not be the sole responsibility of government, but should be shared between:

i) the individual beneficiaries who should fund higher education through financial support from their families, churches, philanthropic individuals and non-governmental organisations, community based groups and financial institutions, including insurance companies.

ii) the educational institutions should also get involved in sourcing for funds. (Soludo, 2004, p.10).

In respect to sourcing for funds by universities, Lamptey (1994) identified the different types of costs or prices rather (Doss, 2014) in any organisation and how to manage them. These include the fixed costs, which do not vary with the unit of production. Fixed costs are referred to as the overheads and they are incurred whether or not the organisation produces. Examples of fixed costs are staff salaries, which must be paid to pensionable staff. The next type of costs is the variable costs, which vary with the units of production. Boarding and lodging costs fall within variable costs category. The two costs (fixed and variable) add up to the total cost. Lamptey (1994) advised that for higher educational institutions in Africa to continue to function and succeed, they should:

i) set realistic prices and they should use break-even analysis to double-check that revenue, at least, cover the variable costs even when profits are not desired (Lamptey, 1994). Such a measure is expected to reduce imbalances between cash in-flow and out-flow; and they should also

ii) pursue other sources of funding to cater for capital development needs. (p.6).

To enable them break even with variable costs, Lamptey (1994) recommended that higher educational institutions in Africa, which include universities in Nigeria should fix different prices for different disciplines and levels of study. For example, students majoring in Medicine should pay a different price from students majoring in the Arts disciplines, because the former requires the purchase of more materials by the institutions than the latter. In the same vein, a student studying to obtain first degree should pay less than their counterparts who study to obtain higher degrees. Each higher educational institution should decide on how many places they reserve for students deserving scholarship and how many they allocate to indigent students. Block tuition fee for higher education was strongly discouraged by Lamptey (1994).

In the opinion of Lamptey (1994), until unit costs are determined by higher educational institutions in Africa, their bargaining power with their markets, particularly with government will remain weak. This prediction is true as evidenced in Nigeria. Bigger amounts of money are budgeted for education every year, but the excess amount is consumed by inflation, which causes prices to rise, including the unit cost of educating a student. The writer's university discriminates on charging students as shown in Tables 3-4. 
Table 3. 2012/2013 Summary of Sundry Charges Payable by 400, 500, 600 Level Students

\begin{tabular}{|c|c|c|c|c|}
\hline SN & Faculty/Programme & CHARGES $\mathrm{F}$ & LEVELS 400, & \\
\hline 1 & ARTS FACULTY & A Semester 1 & A Semester 2 & \# Total \\
\hline $1 \mathrm{a}$ & Communication Art/Theatre Art/Music & 13,600 & 12,000 & 25,600 \\
\hline $1 b \& 2$ & $\begin{array}{l}\text { Other departments in Arts/Business Adm., Law/ } \\
\text { Social Science }\end{array}$ & 11,100 & 9,500 & 20,600 \\
\hline $3 a$ & $\begin{array}{l}\text { Agric/Pure Sciences/Technical/Agric/Education/Basic } \\
\text { Medical Sciences }\end{array}$ & 12,100 & 10,500 & 22,600 \\
\hline $3 b$ & Other departments in Education & 11,150 & 9,500 & 20,600 \\
\hline 4 & CLINICAL SCIENCES/PHARMACY & 13,350 & 11,750 & 25,100 \\
\hline 5 & ENGINEERING/ENVIRONMENTAL STUDIES & 13,100 & 11,500 & 24,600 \\
\hline
\end{tabular}

Source: Bursary Department, University of Uyo (2014, October).

NB: One dollar $(\$ 1.00)=$ One hundred and fifty five Naira (\$155.00)

One British pound $(£ 1.00)=$ Three hundred Naira $(\$ 300.00)$

Looking at Tables 2 and 3 the Charges on level one students are obviously higher than charges on students at the higher

Table 4. Range of Incomes Generated at the University of Uyo from Different Disciplines and programmes from 2006/2007-2010/2011 Session

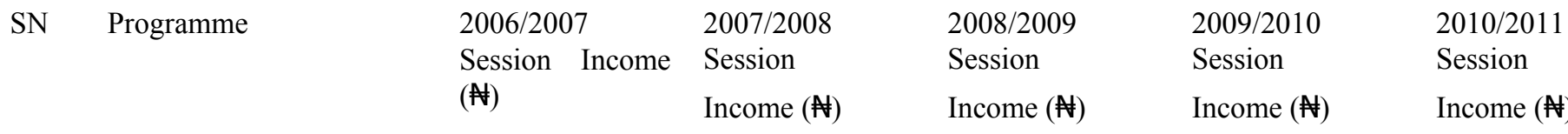

1 Continuing Education

$\begin{array}{lllll}122,530 & 128,600 & 137,468 & 160,776 & 230,500\end{array}$

2 Sandwich

$\begin{array}{llll}13,780 & 14,350 & 15,588 & 15,588\end{array}$

3 Regular under-graduate

463,680

482,730

521,827

581,184

159,600

$4 \quad$ Post-graduate

98,250

103,800

114,774

152,729

Source: Bursary Department, University of Uyo, (2012, September).

Legend

1. One dollar $(\$ 1.00)=$ One hundred and fifty five naira ( $\$ 155.00)$

One British pound $(£ 1.00)=$ Three hundred Naira $(\$ 300.00)$

2. The financial figures are entered in thousands of naira

3. Continuing Education programmes benefit students who study part-time. Classes start from 4:00 p.m. Continuing education students are not covered in the free tuition policy. They are charged fees. Due to insecurity in Nigeria, classes are not expected to last beyond 8:00 p.m. 
4. The Sandwich programme is the programme designed for primary and secondary school teachers who enroll to study during the vacations. The Sandwich programme is not covered by the free tuition policy of the federal government of Nigeria.

5. Just like the sandwich and the Continuing Education programmes, post graduate students are charged tuition fees because the free tuition policy does not cover post graduate programmes.

It should be noticed from Table 4 that even when regular undergraduate students do not pay tuition fees, the largest amount of revenue derived from charging students is from regular undergraduate programmes, followed by charges from Continuing Education programmes. A possible explanation for this has to do with the number of students enrolled in each of the programmes. The regular undergraduates constitute the largest population in the University of Uyo.

\subsection{Funding by Utilizing Innovative Education Distribution Channels (Place Mix)}

The place or distribution channel decisions are taken through answers to such questions as "how does the product get to the target group?" (Lamptey, 1994, p.8). In terms of universities, they should give answers to such questions as:

i) What proportion of candidates who qualify for admission can be admitted?

ii) What proportion of students admitted can be accommodated in hostels?

iii) What off-campus arrangements can be put in place for candidates who meet minimum entry requirements but cannot gain access? (Remedial or Pre-degree programmes)?

iv) What opportunities are there in Distant Education, Open University, part-time or correspondence courses?

Higher educational institutions in Africa including Nigeria are strongly advised to strive to utilize the potentials enshrined in these dissemination channels. They are urged to make distribution (dissemination) decisions, not only of research, but also of teaching and learning. The distribution channels used by the University of Uyo include the following:

i) Tuition free for full-time students in 12 Faculties, including the Law Faculty.

ii) Continuing Education Studies for candidates who for one reason or another could not be selected for full time studies, especially those who are in full-time employment. This set of students pay tuition fees and their lectures start in the afternoons.

iii) Sandwich programme for serving teachers who have put in at least five years of teaching (vacation studies).

iv) Long Vacation Studies for final-year undergraduates who have not more than four final-year failed courses (Discontinued).

v) Pre-degree programme for science-based students.

vi) Mature Students' Programme (Discontinued).

vii) Diploma programmes in Business, Law, French and so on.

viii) Post-Graduate Diploma in Education for graduates who seek careers in the teaching profession.

ix) Affiliations with Colleges of Education and Bible Colleges for the award of degrees.

x) Linkages with universities overseas for research, scholarship and equipment supplies.

xi) Donations from staff unions, subject departments and Alumni.

xii) Donations from public spirited individuals and organisations within and abroad, including banks and research institutes.

xiii) Consultancy services to industries co-ordinated by the Consultancy Unit and individual departments.

xiv) Research grants from Foundations to the academic staff.

The University of Uyo lags behind in the area of establishing links with industries on a large scale, probably because the university is not located in an industrial city. Nevertheless, the current management of the University of Uyo, under the able-leadership of Professor (Mrs.) Comfort M. Ekpo has initiated actions to that effect. 


\subsection{Innovative Funding Through the use of Marketing Communication Strategies (Promotion)}

The marketing promotion framework encourages universities to use promotion of their products and services as a funding strategy. Based on Lamptey (1994), a marketing communication tool has five traditional components, which are:

i) advertising (ii) publicity iii) public relations;

ii) personal selling; and (v) sales promotion. (p. 13)

A common model of the communication process involves the sender who encodes the message through a channel to the receiver who decodes, responds or sends a feedback to the sender. The message sent may not reach the receiver in the form it was intended, because it may be distorted by noise in the channels. Lamptey (1994, pp.13-14) recommends the use of the following promotional activities to raise funds for higher education.

- Informing people far and near about the availability programmes, and activitiesincluding the general progress and drawbacks of the institution. Universities in Ghana meticulously use this channel and they pull a large number of foreign students, particularly from Nigeria.

- Reassuring people of the quality of the existing programmes and services.

- Reminding the stakeholders about their obligations and responsibilities towards the institution.

- Persuading the stakeholders to support the work in the institution. Asodike (2008) listed areas where community members could help as including donation of money and equipment, volunteering services and being advocates (go-betweens) of the students and the institutions' policy implementation. The University of Uyo does this religiously by regular meetings with parents; where agreements are reached agree on how much parents could help through charges on their children.

- Deciding on which promotional component or a mixture of them that bests suit a particular purpose. According to Lamptey (1994) personal selling or public relations can be used by top management and faculty members at no cost. An exhibition, a seminar or formal advertisement are fund sourcing avenues at minimal costs. Higher educational institutions in Africa are advised to go beyond their News Bulletins. They should buy spaces in national and international publications to advertise their programmes and show-case their capabilities and achievements. They should attract foreign students.

The University of Uyo does a lot of promotion through advertisement in newspapers, and through radio and television programmes. Seminars are also highly utilized by all Faculties. The University of Uyo Library, the Engineering and Agricultural Science Faculties, regularly exhibit their products and the Theatre Arts and Music departments regularly showcase their products. Indeed, products from the Fine Arts Department adorn the town campus. The university has foreign nationals among the academic staff and in the student population. It has linkages with universities in Europe, America, Asia and in other African countries (Ekpo, 2014).

\subsection{Entrepreneurial Model of Funding Education}

Higher educational institutions in Africa are expected to engage in entrepreneurial activities (Soludo, 2004). In other words, higher educational institutions are expected to 'do businesses just like the private sector; to compete and to survive. This may sound strange to authorities who are familiar with Parson's (1961) typology of organisations that puts educational institutions in a different class from the business sector.

Be that as it may, the University of Uyo does not lag behind in pursuing entrepreneurship. Reports from the Vice Chancellor (Ekpo, 2014) paints a beautiful picture of the envisaged entrepreneurial activities. These include Songhai Farming of which personnel are now undergoing training and bottled water which is now commercialized. Entrepreneurial activities are envisaged not only for financial gains, but also as a source of skills for students to acquire. It is believed that entrepreneurship by the University of Uyo will play a tripartite role. It is not only for fund generation, but also for practical-skill training and for employment of students. One of the challenges for graduates in Nigeria is lack of opportunity for practicing the skills acquired in schools. It is therefore hoped that the pursuit of these ventures will open practical skills and wider employment opportunities for University of Uyo graduates. (Inyang \& Etuk, 2015).

\section{Innovations in Quality Control Practices}

As Obanya (2003) earlier observed, most educational reforms usually centre around two issues. These are the issue of relevance and educational quality. Effecting changes in education for quality and relevance are two evaluative criteria of educational systems, which are delicately interwoven. The aim in education at any point in time is to 
pursue something which is worthwhile. Something which is worth-while must be something of quality and relevant to the needs of the seekers.

Quality defines the worth of an item; it describes people's perception of how good or how bad the thing is. Quality of education in this context refers to the perception of the stakeholders and consumers of how good or how bad the educational system is. The criteria of a qualitative education include: teaching the learners who are exposed to it what it purports to teach; equipping learners with knowledge and skills, and inculcating in them certain values, attitudes and emotional dispositions, which would make them contributing and law-abiding members of society. In other words, such an education is one that gives holistic learning experiences to learners for their all-round development. This refers to development in all three areas of knowledge as identified by Bloom (1956). In the cognitive domain, learners who are exposed to a qualitative educational system should be able to read, comprehend, apply, and analyze any information presented to them. In the affective domain, learners should develop their preferences and values to the extent of developing their identities around certain values; and their attitudes and emotions should be well controlled. In the psychomotor domain, learners should develop skills in the use of their hands to handle equipment and to solve common problems in homes; they should acquire good information and communication skills, and they should use their different body parts for creative purposes. These include developing the ability to use the hands, feet, tongue, and voice and so on. Educational inputs in a qualitative school should include good teachers, efficient learning materials and infrastructure, effective management of the educational system and good students. In addition to these, the teaching and learning processes should be of very high standards. Combining excellent inputs and processes is expected to produce well-equipped graduands (products).

Relevance of education to industry and to life outside the school setting has become a major educational concern in Nigeria. Educational programmes and their contents are now carefully scrutinized to eliminate theoretical and extraneous items from the curriculum of every level of education and they are replaced with more practical knowledge and skills. Universities are challenged to produce graduates who possess certain values, skills and academic experiences that are relevant to industrial needs and thus enhance their employability.

Educational programme mounted in schools are some of those phenomena that are very resistant to change. Some educational programmes can remain untouched and without any modifications for a number of reasons. One reason is the examination system, which like at the secondary education level in Nigeria, involves all the schools mounting the same curriculum because final examinations are controlled by the same examination agencies-the West African Examinations Council (W.A.E.C.) and the National Examinations Council (N.E.C.O.). Effecting changes for relevance at the secondary school curriculum, therefore, becomes almost impossible for schools which must teach based on the curriculum requirements of the examinations for which the students are prepared. The same obtains in higher educational institutions in Nigeria, where the learning contents are determined by the respective controlling agencies. At the university level, the National Universities Commission (N.U.C.) dictates programme benchmark for universities in Nigeria; just as the National Board for Technical Education (N.B.T.E.) and the National Council for Colleges of Education (N.C.C.E.) do for polytechnics and colleges of education, respectively. This may be part of why curriculum development activities tend to be lacking in schools/colleges/universities in Nigeria.

Quality assurance is the concern for the appropriateness of the curriculum design, adequacy of resources, the focus by students and staff, programme standards and support services, all of which are significant to the quality of products from educational institutions and consequently, on standards in society. According to Ekong (2007), quality assurance practices in universities are meant to:

- ensure that the provision in the minimum academic standards documents are attained, maintained and enhanced;

- assure employers and societal members that graduates have attained acceptable levels of competence in their areas of specialisation; and

- to inform the international community that academic programmes in Nigeria are of high standards and graduates are adequately developed for post-graduate studies and employment (p.5).

It is widely held that a qualitative university education should help students to acquire innovative skills, variously called employability skills (Taylor, 1999); "daily-living skills" (Okebukola, 2002, p.35), "generic skills" (Obanya, 2002), "life-coping skills" (Obanya, 2003, p.3; Njogu, 2003, p.22). The list of such skills as supplied by Obanya (2003) include: versatility in knowledge; the capacity to communicate and appreciate the views and feelings of others; ability to adapt to novel situations; literacy in its comprehensive dimensions; fluency in information and communications technology (ICT) and the capacity to embrace learning as a way of life. (p.3). Quality assurance activities in universities in Nigeria of interest in this paper include strategic planning; innovative educational curriculum enriched with general studies courses, standardization of students' admission procedures and limiting the 
carrying capacities of individual universities, accreditation of university programmes and accreditation of the entire university.

\subsection{Quality Assurance in Planning}

Strategic planning is a long-term planning which according to U. Etuk (2005) requires heads of university departments and faculties to state the objectives of their academic programmes and state in concrete terms what graduates of those programmes would be capable of doing, or show how they would contribute to the economy when they go out into the world of work. Administrators are expected to spell out what they see as their strengths, weaknesses, opportunities and threats (SWOT analysis). They are expected to give details of how much money they require to achieve their visions and how much money they could raise through their own internal resources. In effect, strategic planning require university administrators from the lowest to the highest level to rationalize on why they should attract government funding for their different programmes and projects. Strategic planning concept incorporates the issue of competition, involvement in entrepreneurial activities by universities and sourcing for funds without overdependence on government. (Innovations in funding is discussed in a separate section of this paper)

\subsection{Quality Assurance Through Innovation of the Learning Contents}

Curriculum change is a regular feature of educational systems in Nigeria. Soon after the Nigeria independence in 1960, those contents and examples which were completely foreign to learners in Nigeria were dropped in preference for familiar contents, illustrations and examples (Yoloye, 1993). From 1976, however, the educational system was completely restructured from 6-5-2-4 to assume what is popularly known as the 6-3-3-4 educational structure. That means that secondary education changed from the five-year duration to six years, broken into two equal parts of three-year durations each (the junior secondary of three years duration and the senior secondary of the same duration). Moreover, two years of post-secondary education was scrapped. The new educational structure came with enrichment of the learning contents (renewing the curriculum) at all levels of education. Without prejudice to what obtained before that time, the most memorable holistic review of the learning contents in universities in Nigeria took place in the 1985/86 session. That was when the first set of secondary school students "graduated" from the 6-3-3-4 educational system and were admitted for higher education.

Based on the benchmark directed by the Nigeria Universities Commission (N.U.C.), the learning contents in universities were changed, probably to incorporate some of the contents which were earlier taught at the post-secondary school (Higher School) level. The two-year Higher School was scrapped in preference for the 6-3-3 4 structure, which Nigeria education was made to assume since 1976. The development of vocational and technical skill was highly emphasized in the 6-3-3-4 educational system and the learning contents needed to be changed at every level of education to suit that new emphasis. Education in the new structure was meant to be more functional than hitherto. It was meant to emphasize all the three domains of knowledge-cognitive, affective and psychomotor domains. Thus, learning programmes in the 6-3-3-4 system were meant to promote all-round development of learners. The graduates from that system of education were expected not only to be very employable, but also to possibly, be employers of labour (Federal Republic of Nigeria, 1981).

In the same vein, the curricula of tertiary education were innovated in the 1985/86 session when new courses called "General Studies" (GST) courses were introduced. The National Universities Commission (N.U.C.), a body set up by government to manage the university system supplied a benchmark of course descriptions, which every university department was mandated to mount for its students, including the GSTs.

The GSTs are university-wide (core) courses, which are mandatory for every university student in Nigeria. They are core courses designed to: give the students general knowledge about the environment, the world around; enhance communication abilities of students, literacy in information and communications technology (ICT); and inculcate entrepreneurial skills. At the author's university, the GSTs include a 3-units course in the humanities titled "The Use of English"; a 3-units course in the Social Sciences titled, "The Nigeria People and Culture"; a 2-units course in the Sciences titled, "History and Philosophy of Science; two 3-units courses in Introductory Computer Studies; a 3-units course each on citizenship education and on "entrepreneurship education", respectively. The latter was introduced in the 2012/2013 session. In addition to the GSTs there are compulsory Faculty-wide courses, which vary depending on which faculty a student belongs to. The Faculty of Education of the University of Uyo, has two 3-units courses in Curriculum Studies; two 3-units courses in Educational Psychology; two 3-units courses in Research Methods and Statistics; a one-unit introductory course to the teaching profession; and a 3-units course in educational management. The GSTs and the Faculty-wide courses are mandated by the National Universities Commission (N.U.C.), the management body for university education in Nigeria. These courses are designed to give general education to all graduates from universities in Nigeria and common educational experiences to graduates from the same discipline. In addition, students from the Faculty of Education undertake 12 weeks of practical teaching in primary and 
secondary schools. Students who are prepared for skilled occupations, like Engineering, the Sciences, Vocational and Technical education, go on industrial attachments as a basic requirement for graduation.

\subsection{Quality Assurances Through Innovations in Students Admissions (Standardisation of Requirements)}

Standardisation of admissions into universities came very early in the history of university education in Nigeria. The Joint Admission and Matriculation Board (J.A.M.B.) was instituted since the 1977/78 session to select qualified candidates for admission into universities in Nigeria through the administration of entrance examinations. When it worked well for the universities, the admission duties of the J.A.M.B. were extended to the other tertiary educational types, particularly admission of students into Polytechnics and Colleges of Education. Prospective tertiary education entrants must have the prescribed number of credits for the preferred type of tertiary education, including credit passes in Mathematics and English language, at the ' $\mathrm{O}$ ' level (secondary school level). A candidate must in addition, attain an acceptable pass level in the Unified Tertiary Matriculation Examinations (U.T.M.E.), which is a J.A.M.B.-administered entrance examination. However, the power of JAMB seems to be eroded in recent years. From the 2005/2006 session universities in Nigeria individually administer "aptitude tests" to the candidates posted to them by the J.A.M.B. A candidate who has a high average score in both the U.T.M.E. and the university-administered aptitude test stands a good chance of being admitted into the preferred discipline.

Placing a limit on the carrying capacities of universities by the N.U.C. is another facet of standardisation of admissions. Universities are entitled to admit a specified number of students in a given discipline in any particular year (restricted carrying-capacity). The carrying-capacity is instituted by the N.U.C., the agency responsible for co-ordinating university education in Nigeria. Despite, the limits set by the N.U.C. Universities are observed to be thickly populated. This is what is referred to as "massification" (Zeelen, 2012, p.360). Massification is a situation of admitting a lot more students than the available facilities. Massification in universities in Nigeria seems to result from a number of factors. One of the factor is liberalization of education which has been the feature since 1970 following the end of the Nigeria civil war. The other reason is the defective system of education, which prepares every child towards one type of tertiary education (the academic type). There is little or no diversification into the vocational and technical fields. This makes cognitive knowledge the only option open to many tertiary education candidates in Nigeria. Added to this is the increasing population of youths and the general tendency for educated Nigerians to detest vocational fields. These have jointly caused massive numbers of students in universities. E. Etuk and Uya (2015) mentioned overcrowded classes as being additional challenges to teacher education in universities in Nigeria. Massification and over-crowdedness are features which are contrary to predictions by Bayer (2014, July 31) that driven by new technologies, new delivery systems and changing consumers habits, populations in universities are likely to dwindle. It is not so over here! Populations are becoming larger and larger every academic session.

To probably create awareness to candidates that opportunities are also available for self-improvement through education in polytechnics and colleges of education, the Joint Admission and Matriculation Board (J.A.M.B.) nowadays design a common application-for-admission forms into the three main types of tertiary education, (universities, polytechnics and colleges of education). Candidates are expected to order their choices of the three tertiary education types, based on their aptitudes and interests. In almost all cases, the university is the first choice and in some cases, all three choices made by a particular candidate are the university. Tertiary candidates in Nigeria do not often feel obliged towards the polytechnic or the college of education. Those who study in polytechnics and colleges of education are constrained to study there by their low U.T.M.E. scores. All these have contributed to massification of students' populations in universities in Nigeria. In many cases university administrators feel very frustrated when admission is denied certain candidates with very good scores. This happens because there are too many good candidates seeking admission into one particular programme, which has a limited carrying capacity and only the top best candidates are chosen.

Massification (Zeelen, 2012) in students' populations is accompanied by two other innovations, namely: low-age of under-graduate students and gender equity in the students' populations. Many candidates who qualify to enter the university are in their teenage years (14-15 years of age) and much more females than before qualify for university education.

\subsection{Quality Assurance Through Innovations in Human and Material Resources Development}

Human and material resources are, in economic parlance, factors of production. The other factors of production are land and capital. Of recent, human ingenuity/entrepreneurship has been added to the list (Ande, 2011). Based on the system's perspectives, all factors of production are inputs into the production process. Altering the constituent of any factor of production, or the processing strategy determines the quality of the final product.

Although human and material resources are both factors of production, they do not command the same valuation in the production process. Human resources are said to be the active elements in the production process while material 
resources are the inactive elements (Moonhead \& Griffin, 2002). The two factors of production are differentiated with the explanation so that it is the human resources that put the material resources into use. Thus, no matter the amount of material resources possessed by an organisation, without the human resources to put them to use they would lie wasted. In effect, proponents of the human resource concept (cf. Moonhead \& Griffin, 2002) emphasize that the human elements of production must be given greater attention by the employer than the material resources, which are often re-furbished and maintained as the case may be. It is emphasized that more care given to material resources must be given to human resources. Modern emphases on managing the human elements in work organisations are on planning all activities that concern the human element, fixing living wages and relating amicably with staff until and after retirement (Goss, 1994). Human resource management functions include human resource planning, recruitment and selection, induction/orientation, compensation, development, performance appraisal, employee relations and severance/retirement planning (Castetter, 1981; Goss, 1994). Human resources management in educational organisations are geared towards improved staff performance and enhanced effectiveness of the organisations. This paper will review just two innovations in human resource management. These are capacity building and retirement planning.

In terms of the human resources capacity-building there are lots of opportunities in the universities of interest for both teaching and non-teaching staff. Both categories of staff nowadays enjoy employer-sponsored workshops, seminars and conferences, especially when such activities are organised by professional groups of the beneficiaries. In addition, both categories of staff are afforded the opportunity for further education on the platform of staff development. Moreover, the non-graduate staff are permitted to further their education and earn university degrees through part-time studiesin their employer university provided they have the entry qualification into the programme of choice. Another innovation of note in respect to staff development concerns the teaching staff, who are bound by the stipulation that earning a doctorate degree is the minimum qualification for lecturers. These staff development policies have greatly helped to build staff capacity. It is assumed that the higher the educational attainment of staff, the better the quality of their services the better the products from universities.

Material resources include the physical facilities and the school plant. The school plant refers to long-lasting assets like school buildings and grounds; the school libraries, laboratories, workshops and equipment. The school vehicles, furniture, books, computer sets and their accessories, radio sets, tables, desks, chairs, stools and file cabinets, though not as long-lasting as those earlier mentioned, are school assets, which are included in this category.

Generally facilities in the universities of interest have been greatly innovated. Thanks to accreditation exercises conducted in universities and on their programmes, organised by the National Universities Commission (N.U.C.). Anticipation of accreditation visits have cause management of universities to pay greater attention to the provision of teaching facilities. On the whole, type-writers have given way to computers and black-boards to white-boards in university offices and classrooms. Universities are linked to the world-wide web and electronic mails have substituted writing with pen and paper. Innovative retirement planning started in the year 2006 in federal establishments in Nigeria, Federal universities, along with other Federal civil servants are covered in the innovative retirement scheme. Under the new scheme, a staff contributes a certain percentage of his/her monthly salary and the employer contributes an equal amount. The total monthly contributions are managed by a fund management enterprise. There are several of such enterprises in Nigeria. The activities of the fund managers are checked through policies put forward by a central body called the Pension Commission of Nigeria (PENCOM).

On retirement, the fund manager pays a certain percentage of the accumulated fund to the retiree client as lump sum, keeps some part for future monthly withdrawals; and takes a certain percentage of the savings as gratis for handling the fund for the client. This implies that retired staff no longer depend on the employer (government) to pay their gratuity and monthly pensions. As at now, it seems like this innovation in retirement scheme is implemented in federal establishments only. State civil servants still look up to state governments for their gratuity and monthly pensions. It is difficult to make a lasting verdict of the innovation in retirement planning. So far, federal retirees seem to fare better than state retirees in the sense that, federal retirees get their retirement benefits more readily than state civil servants. Some private universities have also embraced the new retirement scheme.

\subsection{Quality Control through Accreditation of Programmes}

In addition to the other quality assurance measures, tertiary educational institutions are charged e responsibility of presenting their programmes for accreditation. The accreditation teams are constituted trom peer professionals in respective disciplines by the N.U.C., the co-ordinating agency. In some cases, professional organisations conduct accreditation as well. This is the case with Medicine, Law, Accounting and Pharmacy, that their programmes must be inspected and approved by teams of peers sent by both the N.U.C. and a different team sent by the Council of the respective professional body. 
The N.U.C. accreditation criteria include availability of well-articulated learning programmes (curricula), handbooks for students and staff, teaching/learning facilities, well-stocked libraries; impressive arrays of qualified staff and employers' rating of products from the programme. Each accreditation criterion is assigned some points, and the total points scored, when added up, are used to decide whether a programme is approved to run or not. At the end of the accreditation visit a university programme is placed in either of three categories: full, interim or denied accreditation. A programme that has denied accreditation status is not permitted to admit new students for two consecutive sessions, during which time the failed programme is refurbished and re-presented for inspection by the accreditation team made up of peer lecturers drawn from other universities in Nigeria. A programme that has interim accreditation status is re-visited in two years-time, while a programme that has 'full accreditation' status is revisited in a minimum of a five-year period.

Apart from programme accreditation, the entire universities are subjected to national and international rankings based on similar criteria as earlier mentioned, particularly on the quality of academic staff in a given university, the infrastructures and the entire academic environment. All these attempts are meant to shape up universities, their programmes and personnel working in them, towards fulfilling higher level needs characteristics of the modern world. Universities in Nigeria are meant to meet the modern world standards and to become enhanced centres of excellence (Chukwurah, 2005).

\section{Conclusion}

This paper has highlighted certain innovations in universities in Nigeria. These include innovation in ownership of universities, innovation in funding strategies and innovation in quality assurance practice which include strategic planning; innovations in the learning contents; innovations in human and material resources development, in students' admission, including regulations touching the carrying capacities of universities. Accreditation of university programmes and accreditation of the entire university systems constitute more quality assurance practices mentioned in this paper.

Although these are by no means the only innovations in universities in Nigeria, they have at least, given an insight into what obtains, which have helped to improve programme standards and products' quality. The innovations are compiled from the perspective of the author of this paper, who draws from insights and wealth of experiences as a university teacher in a somewhat, young university in Nigeria.

\section{References}

Ande, C. E. (2011). Essential economics ( $3^{\text {rd }}$ ed.). Ibadan: Tonad Publishers.

Asodike, J. D. (2008). Towards verile parents and community involvement in the management of education for sustainable development. In J. B., Babalola, G. O. Akpa, I. Hauwa \& A. O. Ayeni (Eds.). Managing education for sustainable development in developing countries. Ibadan: Nigerian Association for Educational Administration and Planning (NAEAP). PP. 413-420.

Bayer, R. (2014, July 31). The future of higher education depends on innovation. Retrieved 08/03/15 from: www.forbes.com/.../innovation-should-be-mandatory-in-higher-education

Bloom, B. (1956). Taxonomy of educational objectives: Handbook 1. New York (N.Y.) David Mckay.

Castetter, W. B. (1981). The personnel function in educational administration ( $3^{\text {rd }}$ ed.). New York. N. Y.: Macmillan.

Chukwurah H. (2005, Thurs., Sept. 1). Nigerian Varsities for world ranking. Daily Sun (p.12)

Doss, H. (2014, July 31). The future of higher education depends on innovation. Retrieved 08/03/15 from: www.forbes.com/.../innovation-should-be-mandatory-in-higher-education

Ekong, E. E. (2007). An overview of quality issues in the Nigerian university system. In U. Etuk (Ed.). Injecting quality into universities, pp. 3-20. Uyo: Minder.

Ekpo, C. M. (2014, Aug. - October). I have put structures in place that can launch University of Uyo to world class. Education Today International. (pp. 14-18)

Etudor-Eyo, E. U. (2011). Higher educational institutions in Nigeria. In S. U. Bassey (Eds.) Management of higher education in Africa (pp. 1-18). Uyo: Abaam.

Etuk, E. N \& Uya A. O. (2015). The challenges of teacher education in Nigeria. Journal of Research and Development, 6(11), 124-133.

Etuk, G. K. (2006). Education financing for colleges and universities. Uyo: Abaam. 
Etuk, G. K. (2012). Funding of higher education. In S. U. Bassey \& U. U. Bassey (Eds.). Management of higher education in Africa (pp. 368-398). Uyo: Abaam.

Etuk, U. A. (2005). Restructuring the humanities curriculum to meet the needs of globalisation. Nigeria Journal of Curriculum Studies, 12(2), 63-73.

Federal Republic of Nigeria. (1981). National policy on education. Ikeja, Lagos: Federal Government.

Goss, D. (1994). Principles of human resource management. London: Routledge.

Guobadia, A. I. (1982). The environment of higher education. In S. Adesina, K. Akinyemi \& K. Ajayi (Eds.). Nigerian education: Trends and issues (pp. 154-168).

Harbison, F. H. (1973). Human resources as wealth of nations. London: Oxford University Press.

Inyang, N. E. U. \& Etuk, G. K. (2015, March). Marketing education for economic survival: The case of University of Uyo. Bristish Journal of Education, 3(3), 14-26.

Juma, C. (2007, April, 27). Innovative approaches, key to financing higher technical education. Business Daily (Africa), p.3. Retrieved 10/10/2010 from: http://belfercenter-ksg. Harvard. Edu/publication/168/html. Innovative approaches: key to financing higher education.

Kotelnikov, V. (2000). Innovation management. Virtual venture rally, Retrieved, Aug. 8, 2009. From: Fun 4Biz.com

Lamptey, A. S. (1994). Financing higher education in Africa: a marketing perspective. A paper written in the university of Ghana Consultancy centre. Legion, Accra, for Dakar Regional Office, BREDA Series Number 5.

Moonhead, G. \& Griffin, R. W. (2002). Organisational behaviour ( $5^{\text {th }}$ ed.). New York, N. Y.: Houghton Mifflin.

Njogu, J. E. (2003). Acquisition of life-coping skills: The future direction. Nigeria Journal of Curriculum Studies, $10(1), 22-27$.

Obanya, P. (2002). Revitalising education in Africa. Ibadan: Stirling Hordan.

Obanya, P. (2003). Contemporary world concerns and the African School Curriculum. Keynote address at the $16^{\text {th }}$ Annual Conference of the Curriculum Organisation of Nigeria $(\mathrm{CON})$, University of Port Harcourt, Port Harcourt, $25^{\text {th }}-29^{\text {th }}$ Nov.

Ocho, L. O. (2006). Funding initiatives in higher education. A paper presented at the $30^{\text {th }}$ Annual Conference of the National Association of Educational Administration and Planning (NAEAP), Oct. 23-27. Enugu State University of Technology (ESIT) Enugu.

Ogar, O. G. (1992). Fundamentals of education finance. Port Harcourt: University of Port Harcourt Press.

Ojiabor, O. (2005, Mon. Jan. 10). Varsity may rise to 100 in 2007.

Okebukola, P. (2002). Beyond the stereotypes to new trajectories in science teaching. Abuja: Science Teachers' Association of Nigeria (STAN).

Olugbile, S. (2006, Tues. June, 13). 10 more Varsities may emerge before December. The Punch, 17 (1956), p.42.

Parsons, T. (1961). Structure and process in modern society. New York, N.Y.: Free press

Robbins, S. P. (2000). Organisational behaviour $\left(9^{\text {th }}\right.$ ed.). New Delhi: Prentice Hall of India.

Soludo, C. C. (2004). Competition and entrepreneurship as framework for reforming university management in Nigeria. $5^{\text {th }}$ convocation Lecture, University of uyo, March 8.

Taylor, A. (1998). Employability skills: From corporate wish to government policy. Journal of Curriculum Studies, 30(2), 143-164. http://dx.doi.org/10.1080/002202798183675

University of Uyo, Bursary Department (2014). Information on charges for different categories of students was collected from there by the researchers.

Uwajeh, M. C. K. \& Mohammed, A. R. (1988). Highlights of the Nigerian education system. In U. Eleaza (Ed.). Nigeria: The first 25 years (pp. 165-174). Ibadan: Heinemann.

Yoloye, E. A. (1993). Innovation in education in Nigeria. In A. Adaralegbe (Ed.). Integration and innovation in Nigerian education (pp. 220,228). Lagos: Jas/The Nigerian Academy of Education.

Zeelen, J. (2012). Universities in Africa: Working on excellence for whom? Reflections on teaching, research and outreach activities in African universities. International Journal of Higher Education, 157-170. http://dx.doi.org/10.5430/ijhe.v1n2p157 